\title{
Monographical Study of Biological Properties of Argemone Mexicana L. Leaves Extracts: Determination of the Antipyretic Activity on Mice
}

\author{
Sourabie $^{1}$ T.S., Nikiema ${ }^{2}$ J.B., Guissou ${ }^{1,2}$ I.P. And Nacoulma ${ }^{3}$ O.G. \\ ${ }^{I}$ Département Médecine Pharmacopée Traditionnelles/Pharmacie, Institut de Recherche en Sciences de la Santé \\ (MEPHATRA/PH-IRSS), Ouagadougou, Burkina Faso. \\ ${ }^{2}$ Unité de Formation et de Recherche/Sciences de la Santé (UFR/SDS), Université de Ouagadougou, Burkina \\ Faso. \\ ${ }^{3}$ Unité de Formation et de Recherche/Sciences de la Vie et de la Terre (UFR/SVT), Université de Ouagadougou, \\ Burkina Faso.
}

\begin{abstract}
Leaves of Argemone mexicana L. (Papaveraceae) are used in the folk medicine of Burkina Faso (West Africa) to treat a variety of illness. The aqueous decoction is indicated in the treatment of malaria fever, abdominal pains, and jaundice. A preliminary study led by the authors showed a good antihepatotoxic activity of leaves extracts against $\mathrm{CCl}_{4}$-induced hepatic injury in Wistar rats.

The present survey projects to determine the antipyretic activity of a lyophilized water decoction (of Argemone mexicana powdered leaf). The plant extract was tested at 250 and $500 \mathrm{mg} / \mathrm{kg}$ p.o. for its antipyretic potential by using yeast induced pyrexia method in mice.

Both the lyophilized extract (aqueous decoction) was found to exhibit significant $(\mathbf{p}<0,05)$ dose-dependent antipyretic activity in tested model when compared to control group. These results support the traditional use of Argemone mexicana Linn. in pain and febrile disorders in the south werstern area of Burkina Faso.
\end{abstract}

Keywords:- argemone mexicana, lyophilized extract, antipyretic activity, Cascades region, Burkina Faso

\section{INTRODUCTION}

Argemone [6] mexicana Linn. (Papaveraceae) is an herbal medicinal plant originated from Mexico. It is a pantropical spece with a long history of use in folk medicine since the Aztecs period [1]. Argemone mexicana Linn. is also widely well known around the world for its medicinal property to treat several diseases: in India, decoction of the leaves are indicated for the treatment of bacterial infections in the Ayurvedic medicine [2]. In West Africa, A. mexicana is used as uncomplicated malaria remedy in Mali [3]; in Burkina Faso the studies of Sourabié et al., $[4,5,6,7]$ indicated that the traditional medical practitioners recommend utilization of the leave plant mainly for the treatment of malaria and the liver disorders.

In the case of Burkina Faso, according the statistics furnished by INSD, [8], more than 70\% of people still rely on medicinal plants for the treatment of various diseases. And Argemone mexicana Linn. plays an important role in the traditherapeutical domain concerning medicinal plants in the Cascades area (south western part of Burkina Faso).

Moreover, many pharmacological properties described by the traditional medical practitioners about Argemone mexicana have been in great part confirmed by several authors such as Sourabié et al., [4,5,6,7]; Das et al., [9] for the anti-hepatotoxic activity; Willcox [3] for the anti-malarial activity of leaves aqueous extract; Sourabié et al., [6,7] for the antimicrobial, anti-inflammatory analgesic potent. Priya and Rao [10] for muscle relaxant, antifungal, antioxidant, anti-helminthic and wound healing activities, etc.

On the chemical way, many authors have reported that interesting secondary metabolites are shown to be present in the drug [Priya and Rao, [10], Bose et al. [11], Harbone and Williams, [12]; Upreti et al., [13] such as glycosides, tannins, saponins and alkaloids, specially isoquinolein alkaloids type as sanguinarin, dihydrosanguinarin, berberin, protopin, etc.

Thus, the purpose of that present work was to determine on biological way the anti-pyretic property of two oral doses ( $250 \& 500 \mathrm{mg} / \mathrm{kg}$ p.o.) of lyophilized aqueous extract (decoction) of the drug. The choice of aqueous lyophilized extract for the present study is due that water decoction constitutes the main preparation of galenic form used by a great majority of traditional medical practitioners. 


\section{* Plant material}

\section{MATERIALS AND METHODS}

The collection of Argemone mexicana leaves has been done in the period of end December 2004 in Banfora, a town located about $450 \mathrm{~km}$ far from Ouagadougou. A voucher specimen was firstly identified in the laboratory of Pharmacognosy (UFR/SDS, University of Ouagadougou) and then was after deposited in the museum of Botany Department (DPF, INERA/CNRST).There, the authentication of the specimen sample was certified by comparison with the one which was preserved. The registration number of the specimen was HBNU 762

\section{* Biological material}

The biological material was composed mainly by young male and female white mice (rain NMRI), 4-6 weeks old and weighing 25-30 g; they were used to conduct the in vivo experiment. These mice were provided by CIRDES laboratory in Bobo-Dioulasso at $360 \mathrm{~km}$ from Ouagadougou. Before pharmacological experimentation, they were kept in the animal house of the Institut (Département Médecine et Pharmacopée Traditionnelles/Pharmacie) and maintained at a room temperature between 25 and $30^{\circ} \mathrm{C}, 40-70 \%$ humidity conditions and the natural day-night cycle with an ad libitum access to food. They had no access to food during the hole day of experiment and the influence of circardian rythms was avoided by starting all experiments at the same moment (08:30 a.m).

\section{* Extract preparation}

Decoction: aqueous extract was obtained by the decoction of $500 \mathrm{~g}$ of Argemone mexicana Linn. powdered leaf in $2 \mathrm{~L}$ distilled water during 30 minutes. Filtration and centrifugation ( $2500 \mathrm{rd} / \mathrm{min}$ for $10 \mathrm{~min}$ ) were performed to freeze-dry the aqueous extract.

Furthermore, the extract was qualitatively tested for the presence of chemical constituents; phytochemical screening of the extract was performed by using the following reagents: alkaloids with general precipitation reagents as Bouchardat, Draggendorf and Valser-Mayer tests; flavonoids with Shibata test (cyaniding test); tannins with ferric chloride solution $1 \% \mathrm{p} / \mathrm{v}$ ) and saponins with ability to produce stable foam. Liebermann-Burchard test (reagent) was performed to identify the steroids compounds.

\section{* Acute toxicity}

The acute toxicity study per os (oral route) was performed to study the acute toxic effects and to determine minimum lethal dose of the drug extract. The albino mice male and female weighing 25-30 g were used for the experiment. The lyophilized extract was administered orally to the different groups $(\mathbf{n}=\mathbf{6})$ of overnight fasted mice at the dose of $25,50,100,250,500$ and $1000 \mathbf{~ m g} / \mathbf{k g}$ body weight. After administration of drug extract, all the animals were observed continuously for signs of toxicity and mortality during 24 h, 48 h, 72 $\mathrm{h}$ and beyond.

\section{* Antipyretic activity}

Antipyretic activity of drug (lyophilized extract) was measured by using Brewer's yeast induced pyrexia in mice.

For this, several groups of mice ( $\mathrm{n}=6$ per group) weighting 25-35 g have been used; they were constituted as below:

*group I (negative control): distilled water + suspended Brewer's yeast $20 \%$

*group II (positive control) : paracétamol (150 mg/kg p.o.) + suspended Brewer's yeast 20\%

*group III (test group 1) : suspended Brewer's yeast 20\% + lyophilized extract $250 \mathrm{mg} / \mathrm{kg}$ p.o.)

* group IV (test group 2): suspended Brewer's yeast 20\% + lyophilized extract ( $500 \mathrm{mg} / \mathrm{kg}$ p.o.).

The initial rectal temperature of each animal was noted by insertion of a clinical thermometer to a depth of $2 \mathrm{~cm}$ into rectum. And then after mice of control and those of tests groups received subcutaneous injection of suspended Brewer's yeast 20\% (1 mL/100 g bwt). Sixteen $(16 \mathrm{~h})$ hours after initial time $\left(\mathrm{T}_{\mathbf{0 H}}\right)$, the rectal temperature of all groups were measured; negative and positive control groups received orally distilled water. The test group (group test 1 and group test 2) received also orally two doses of the lyophilized extract (250 and $500 \mathrm{mg} / \mathrm{kg}$ bwt p.o.).

Positive control group (reference) equally received Paracetamol (150 mg/kg p.o.); the measurement of temperature carried out at $\mathbf{1 h}, \mathbf{2 h}, \mathbf{3 h} ; \mathbf{4 h}$ and $\mathbf{5 h}$ after oral administration of vegetal drug extract.

The average temperatures of test groups were compared to those of negative and positive control groups. Student test «t Test» was used for what concerning the statistical analyses ( $<<0,05$ vs positive control group). 


\section{* Phytochemical screening:}

\section{RESULTS}

Phytochemical screening revealed the presence of interesting constituents in the drug aqueous extract. The yield of decoction was $5,13 \%$ and the presence of many important chemical constituents (in pharmacognosy) has been noted such as alkaloids, flavonoids, sugars and glycosides, phenolic compounds as tannins, saponins [14].

According many authors as Priya and Rao [10], Upreti et al., [13], Bose et al., [11], the alkaloïdic components of the plant are isoquinoline type and a great number of them possess bioactive properties as berberine, cheilanthifoline, coptisine, muramine, scoulerine, sanginarine and protopine (Priya and Rao, [10]. The results of phytochemical screening are resumed in Table 1.

Table 1: Phytochemical compounds of Argemone mexicana L. leaf powder suspension; (In study of Sourabié et al. (2009)).

\section{PHYTOCONSTITUENTS}

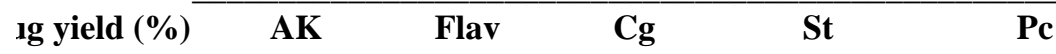

\begin{tabular}{lllllll}
$\begin{array}{l}\text { Aqueous } \\
\text { extract }\end{array}$ & $\mathbf{5 , 1 3}$ & ++++ & + & ++ & + & ++ \\
\hline
\end{tabular}

$\mathrm{Ak}=$ alkaloids; Flav= flavonoïds $\mathrm{Cg}=$ sugars and glycosides; $\mathrm{St}=$ steroids $; \mathrm{Pc}=$ phenolics compounds (tannins); $+++=$ abundant,$++=$ present; $+=$ slightly present

\section{* Acute toxicity test}

The acute toxicity study has shown no toxicity of the drug extract at the dose of $1000 \mathrm{mg} / \mathrm{kg}$ p.o. No mortality was recorded in any group of mice after $72 \mathrm{~h}$ of administering the lyophilized extract to the animals. However, the mice presented muscular weakness with slow movements which disappeared around the end of observation period $(72 \mathrm{~h})$.

\section{* Antipyretic activity}

Oral administration of Brewer's yeast increased the rectal level temperature of the animals (mice) sixteen hours after injection of the pyrexia agent. The lyophilized extract of Argemone mexicana, when given at $250 \& 500 \mathrm{mg} / \mathrm{kg}$ p.o. to the mice, significantly reduced yeast induced fever; the reference drug paracetamol also suppressed fever induced by yeast in mice. All these results are resumed in table 2 (cf. end of manuscript). Table 2 : effect of Argemone mexicana leaf lyophilized extract ( $250 \& 500 \mathrm{mg} / \mathrm{kg}$ p.o.) and paracetamol (150 $\mathrm{mg} / \mathrm{kg}$ p.o.) on brewer's yeast induced fever in mice.

\begin{tabular}{lcccc}
\multirow{2}{*}{$\begin{array}{c}\text { Drugs } \\
\text { Doses }\end{array}$} & \multicolumn{3}{c}{ Average rectal temperature $\left({ }^{\circ} \mathrm{C}\right)$} \\
\cline { 2 - 5 } & $0 \mathrm{hr}$ & $1 \mathrm{hr}$ & $2 \mathrm{hrs}$ & $3 \mathrm{hrs}$
\end{tabular}

$(\mathrm{mg} / \mathrm{kg}) \quad 4 \mathrm{hrs}$

\begin{tabular}{lllllll}
\hline Solvent $(\mathrm{NaCl})$ & $5 \mathrm{~mL} / \mathrm{kg}$ & $37,26 \pm 0,28$ & $37,54 \pm 0,26$ & $37,66 \pm 0,31$ & $37,66 \pm 0,31$ & $37,60 \pm 0,33$ \\
Brewer's yeas* & Susp 20\% & $38,69 \pm 0,30$ & $38,82 \pm 0,38$ & $38,56 \pm 0,38$ & $38,35 \pm 0,52$ & $38,47 \pm 0,20$ \\
Paracétamol & 150 & $38,80 \pm 0,29$ & $37,95 \pm 0,25$ & $37,94 \pm 0,30$ & $37,66 \pm 0,30$ & $37,57 \pm 0,33$ \\
Lyoph* extract & 250 & $38,47 \pm 0,19 *$ & $37,50 \pm 1,08$ & $37,40 \pm 0,40$ & $37,36 \pm 0,66 *$ & $37,28 \pm 0,76$ \\
Lyoph* extract & 500 & $38,57 \pm 0,22$ & $*$ & $*$ & $37,34 \pm 0,26$ & $*$ \\
& & & $37,46 \pm 1,03$ & $37,36 \pm 0,28$ & & $7,22 \pm 0,24$
\end{tabular}

Each datum represents the mean rectal temperature $\left({ }^{\circ} \mathrm{C}\right) \pm$ S.E.M. $(n=6)$, ${ }^{*} \mathrm{p}<0,05$, if compared with the control group (Student test)

Lyoph* extract : lyophilized extract ( $250 \& 500 \mathrm{mg} / \mathrm{kg})$ 
The hyper (elevated) pyrexia induced par brewer's yeast was attenuated one hour (1hr) after administration of the two drug extract $(250 \& 500 \mathrm{mg} / \mathrm{kg})$. The decrease of body temperature of mice was parallel to that exhibited by the reference drug (paracetamol, $150 \mathrm{mg} / \mathrm{kg}$ ); showing thus the reality of a potential antipyretic effect of the lyophilized extract.

\section{DISCUSSION}

Phytochemically, the aqueous extract (decoction) of Argemone mexicana leaves showed interesting phytochemical constituents as indicated in table 1 above. And these chemical principles particularly the alkaloids (isoquinoleine types like sanguinarin, dihydrosanguinarin, berberin, protopin, chelerethryne and dihydrochelerethryne, etc.), flavonoids, sugars and glycosides, phenolic compounds as tannins, saponins supported the biological activities of the plant extract in the present study.

Indeed, acting at 250 and $500 \mathrm{mg} / \mathrm{kg}$ on induced yeast pyrexia, the lyophilized (aqueous decoction) extract showed a dose-dependent antipyretic effect. That dose-dependent antipyretic effect was more accentuated with the extract tested at $500 \mathrm{mg} / \mathrm{kg}$ comparatively to the reference drug (paracetamol used at 150 $\mathrm{mg} / \mathrm{kg}$ ) from the first to the fourth hour ( $1^{\text {st }}$ to $4^{\text {th }}$ hour) as indicated by on table 1 . Figure below give an illustration of the antipyretic effect of the two doses extracts (250 and $500 \mathrm{mg} / \mathrm{kg}$ ) comparatively to the control and paracetamol (reference drug).

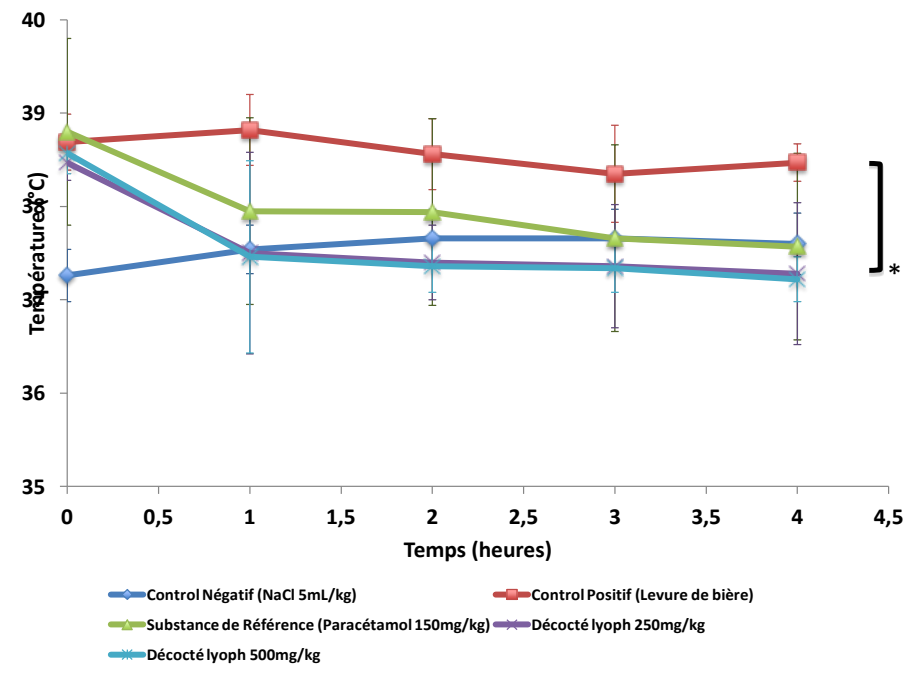

Moreover, the very sensitive reduction of body temperature observed with the mice between the second hour ( $2 \mathrm{hrs})$ and the fourth hour (4hrs) under the effect of the two doses of drug extract $(250 \& 500 \mathrm{mg} / \mathrm{kg})$ when compared to the control supposed the existence of a potential hypothermic effect due to the lyophilized extract (Table 2).

\section{* Mechanism of the antipyretic activity measured}

In a previous study, Sourabié et al. [14] investigated and confirmed the anti-inflammatory and analgesic properties of the lyophilized aqueous extract of Argemone mexicana Linn. in mice by using the same dose extract ( $250 \& 500 \mathrm{mg} / \mathrm{kg}$ ). According to these authors [14], the results of that study showed that the antiinflammatory and analgesic activities of the drug extract have been attributed to the phytochemical components found to be present in the drug extract as alkaloids, glycosides, flavonoids, phenolic compounds as tannins, saponins, etc., confirming thus the findings of authors such as Oweyele [15], Adeolu [16], and Sini et al., [17]. These components exert their biological action according to a mechanism of cyclooxygenase enzymes I and II (COX-1 and COX-2) inhibition which are implicated in the production of inflammation mediating agent prostaglandin (PGE) from arachidonic acid [18,19,20].

The lyophilized extract $(250 \& 500 \mathrm{mg} / \mathrm{kg}$ ) showed a similar pharmacological dose-dependent effect (antipyretic action) on yeast induced pyrexia on mice when compared to the paracetamol (reference drug). Moreover, it is well known that most of the non steroidal anti-inflammatory drugs as paracetamol or lyophilized extract (in the case of this present study) possess antipyretic activity through inhibition of prostaglandins synthesis in hypothalamamus [20,21]. Both the dose extract $(250$ and $500 \mathrm{mg} / \mathrm{kg}$ ) produced significant 
antipyretic activity in Brewer's yeast induced pyrexia in mice. And this situation (both the dose extract $250 \&$ $500 \mathrm{mg} / \mathrm{kg}$ ) could inhibit the prostaglandins synthesis in hypothalamamus.

\section{CONCLUSION}

The results obtained in the present study indicate that the lyophilized extracts of Argemone mexicana Linn. leaves possess antipyretic properties and confirm experimentally on a biological model (animal) that pharmacological property (antipyretic effect) which supports the use of this plant for the treatment of malaria fever in the western part of Burkina Faso.

Acting by its pharmacological potent as anti-inflammatory, analgesic and antipyretic on several illness such as jaundice (icterus), malaria, bacterial gastro-enteritis, etc., Argemone mexicana Linn. (Papaveraceae) occupies an important place in the therapeutical arsenal in folk medicine in Burkina Faso particularly in the "Cascades area".

\section{ACKNOWLEDGEMENTS}

The authors are grateful to the medical tradipractitioners from the villages of Beregadougou and Mondon (Cascades region in Burkina Faso) for their collaboration. Grace to their kind help during the ethnobotanical and ethnopharmacognostical investigations (field visits of reconnaissance of medicinal plants), we have appreciated the richness of the biological diversity of Cascades area for its density in vegetal species on medicinal interest.

\section{REFERENCES}

[1]. Emmart E.W. (1940) The Badianus Manuscript : an Aztec Herbal of 1552. John Hoptkins Press : Baltimore, $M D$.

[2]. Indranil B., Soroj K.C., Soumendranath C., Goutam C. (2006). Antibacterial potentiality of Argemone mexicana solvent extract against some pathogenic bacteria. Mem. Inst. Oswaldo Cruz, Rio de Janeiro, 101 (6): 645-648.

[3]. Willcox M.L., Graz B., Falquet J., Sidibé O., Forster M., Diallo D. (2007) - Argemone mexicana L. decoction for the treatment of uncomplicated falciparum malaria. Royal Society of Tropical Medecine and Hygiene, 101: 1190-1198.

[4]. Sourabié T.S., Nikiéma J.B., Nacoulma O.G., Guissou I.P., (2006) - Etudes préliminaires du pouvoir anti-hépatotoxique d'une plante de la pharmacopée burkinabé préconisée dans le traitement traditionnel de la jaunisse : cas d'Argemone mexicana L. (Papaveraceae). J. Soc. Path. Exot., 2-3 nov. Ouagadougou.

[5]. T.S. Sourabié, H.M. KONE, J.B. Nikiéma, O.G. Nacoulma and I.P.Guissou, (2009) - Evaluation of the antihepatoxic effect of Argemone mexicana leaf extract against $\mathrm{CCl}_{4}$-induced hepatitis injury in rats. Int. J. Biol. Chem. Sci. 3(6): 1499-1503, December 2009.

[6]. T.S. Sourabié, J.B. Nikiéma, I. Léga, O.G. Nacoulma et I.P.Guissou, (2010). Etude in vitro de l'activité antibactérienne d'extraits d'une plante de la pharmacopée burkinabé : cas d'Argemone mexicana L. (Papaveraceae). Int. J. Biol. Chem. Sci. 4(6): 2009-2016, December 2010.

[7]. T.S. Sourabié, J.B. Nikiéma, I. Léga, O.G. Nacoulma et I.P.Guissou, (2012). Etude comparée des effets anti-hépatotoxiques d'extraits d'Argemone mexicana L. (Papaveraceae), une plante utilisée dans le traitement traditionnel de la jaunisse au Burkina Faso. Int. J. Biol. Chem. Sci.6(3):1139-1147.

[8]. Institut National de la Statistique et de la Démographie (INSD) 2007. Analyse des résultats de l'enquête sur les conditions de vie des ménages en 2007. Ouagadougou : INSD, Octobre 2007.

[9]. Das PK, Sethi R., Panda P. and Pani SR (2009)- Hepatoprotective activity of plant Argemone mexicana Linn against carbon tetrachloride $\left(\mathrm{CCl}_{4}\right)$ induced hepatotoxicity in rats. International Journal of Pharmaceutical Research and Development; 8:1-20.

[10]. Priya Charles Lekhya and Kokati V. B. RAO (2012) Ethnobotanical and current ethnopharmacogical aspects of Argemone mexicana Linn: an overview. IJPSR, Vol. 3(7): 2143-2148.

[11]. Bose B.C., Vijayvargiya R, Saifi A.Q., Sharma S.K., (1963). Chemical and pharmacological studies on Argemone mexicana L.. Journal of Pharmaceutical Sciences; 52:1172-5.

[12]. Harborne J.B., Williams C.A.; (1983). Flavonoïds in the seeds of Argemone mexicana: a reappraisal. Phytochemistry ; 22(6):1520-1

[13]. Upreti K.K., Das M., Khanna S.K. (1991) - Biochemical toxicology of Argemone oil. Effect on hepatic cytochrome P-450 and xenobiotic metabolizing enzymes. J. Appl. Toxicol; 28:203-209.

[14]. Sourabié T.S., N. Ouédraogo, W.R. Sawadogo, J.B. Nikiéma, I.P. Guissou and O.G. Nacoulma (2012)- Biological evaluation of anti-inflammatory and analgesic activities of Argemone mexicana Linn. (Papaveraceae) aqueous leaf extract. International Journal of Pharmaceutical and Biological Sciences (IJPSR), Vol 3, N $^{\circ}:$ 451-458. 
[15]. Owele VB, Oloriegbe YY, Balogun EA (2005) - Analgesic and anti-inflammatory properties of Nelsonia canescens leaf extract. J. Ethnopharmacol; 99:1536156.

[16]. Adeolu A. Adedapo, Margaret O. Sofidiya, Viola Maphosa, Busani Moyo, Patrick J. Masika, Anthony J. Afolayan (2008) - Anti-inflammatory and analgesic activities of the aqueous extract of Cussonia paniculata stem bark. Rec Nat Prod; 2(2):46-53.

[17]. Sini K.R., Sinha B.N., Karpakavalli and Sangeetha P.T. (2011) - Analgesic and antipyretic activity of Cassia occidentalis Linn. Annals of Biological Research, 2(1):195-200.

[18]. Parmar NS, Ghosh MMN (1978) - Current trends in flavonoids research. Indian J. Pharm; 12:2136228.

[19]. Barar FSK (2006) - Essential of Pharmacotherapeutics, $4^{\text {th }}$ ed. S. Chand \& company Ltd, New Delhi; p. $106-109 \& 526$.

[20]. Rang HP, Dale MM, Ritter JM, Moore PK. (2003)- Pharmacology, $5^{\text {th }}$ ed. Elsevier Science Ltd, Philadelphia; p.566-572.

[21]. Santos ARS, Filho VC, Niero R, Viana AM, Moreno FN and Compos MM (1994)- J. Pharm Pharmacol., 46:755 